Article

\title{
Reincarnation: Mechanics, Narratives, and Implications
}

\author{
Christopher Key Chapple \\ Bellarmine College of Liberal Arts, Loyola Marymount University, Los Angeles, CA 90045, USA; \\ cchapple@lmu.edu
}

Received: 12 September 2017; Accepted: 24 October 2017; Published: 27 October 2017

\begin{abstract}
This essay explores the mechanics associated with rebirth, noting differences between Hindu, Buddhist, and Jain narratives. It examines the concept of subtle body and the lingam in Sāmkhya. According to the Hindu tradition, the remains of the departed person, when cremated, merge with clouds in the upper atmosphere. As the monsoon rain clouds gather, the leftovers mingle with the clouds, returning to earth and eventually finding new life in complex biological cycles. According to Tibetan and Chinese Buddhism, the remains of a person take a ghostly form for 49 days until taking a new birth. According to Jainism, the departed soul immediately travels to the new birth realm at the moment of death. According to Jain karma theory, in the last third of one's life, a living being makes a fateful choice that determines his or her next embodiment. The 20th century Hindu Yoga teacher Paramahamsa Yogananda, in his commentary on the Bhagavad Gita, provides an alternate description of a twofold astral and causal body. One hallmark of the Buddha and of the 24 Jain Tìrthankaras was that they remembered all the lives they had lived and the lessons learned in those lives. The Buddha recalled 550 past lives and used these memories to fuel many of his lectures. Mahāvīra remembered his past lives and also the past lives of others. Patañjali's Yoga Sütra states that through the perfection of giving up all things, including psychological attachments, one spontaneously will remember past lives. In the Yogavassiștha, a Hindu text, Punya remembers the past lives of his grieving brother as well as his own prior experiences.
\end{abstract}

Keywords: Buddhist rebirth; Jain karma theory; subtle body; astral body; reincarnation

Reincarnation, or punar janma, means birth again. Its conceptual origins remain obscure, though early passages from the Brhadāranyaka and Chāndogya Upanisads (ca. 800 B.C.E.) describe the sacrificial process through which the funeral fire allows a person's remains to ascend into the clouds, return to earth with the rains, become food, and then the semen that begets new life (BU 6.2; CU 5, 3-10). The idea of rebirth eventually gained traction as an eschatological tool, an incentive to improve one's moral standing. The Kaușitaki Upanishad proclaims that those who do good deeds in the world will ascend to a heavenly realm; those who harm others will descend into animal births (KU I:2).

This essay will explore some of the mechanics associated with rebirth, examining the concept of subtle body and the lingam in Sāmkhya - the process through which one remembers past lives according to the Yoga Sütra. After noting the varied ways in which one life is said to move from one body to the next, specific rebirth narratives in Buddhist, Jain, and Hindu literature will be considered. The essay will conclude with an exploratory typology of how past life narratives function to communicate templates for behavior.

\section{Mechanics}

According to the Hindu tradition, an important task to be performed by the eldest son is to open the skull of his departed parent on the funeral pyre, releasing unresolved desires into the atmosphere, where they are carried by the smoke to linger in the upper atmosphere. As the monsoon rain clouds 
gather, the leftovers mingle with King Soma until released by Indra's thunderbolt. They sink with the rain deep into the soil, where they are gathered up into plants. These plants become food eaten by all manner of animals, including humans. The quintessence of food finds its way into the semen of men. By depositing this semen into the warmth of the womb, life continues, and the subtle material of the departed starts a new course within life. This process can take several seasons. On the death anniversary of a parent or teacher, Brahmins are paid to perform Śraddhā rituals to guide the ancestor on his or her journey.

According to the story of the life of the Buddha, when he attained awakening under the Bodhi Tree, he sat there for seven days, working through his system of past life recollection and his profound understanding of dependent origination or inter-being (pratitya samutpada). Then he got up and walked, and sat again for a total of seven days. This repeated an additional five times, totaling seven weeks or 49 days. At the end of this period of reflection, he took up the resolve to teach. He first invited a monk to hear his insights who monk declined the offer. He met up with his former companions, who also had arrived in the town of Sarnath or Deer Park. Just as the Buddha went through a liminal period of 49 days before committing to full life as a teacher that lasted an additional 45 years, so also, according to the Tibetan Book of the Dead and Chinese Buddhist traditions, it takes 49 days for unresolved karmas to find a new home. In Buddhist tradition, the remains of a person take a ghostly form during this period, traveling at will to pursue unfulfilled desires without a body before finding a moment of sexual allurement through which one re-enters the realm of samsara precisely at the moment of union between one's new mother and father. Buddhist funerals, particularly in China and Tibet, last 49 days so that the family and well-wishers can guide their loved one to an auspicious new birth.

According to Jainism, the departed soul immediately travels to the new birth realm at the moment of death. According to Jain karma theory, in the last third of one's life, a living being makes a fateful choice that determines his or her next embodiment (Jaini 2000a). Extreme care to do no harm increases as one nears the golden years, reflected in more frequent fasting and the strengthening of an already vegetarian diet. Jains do not perform elaborate funeral ceremonies, due to their convincement that the soul determines its own path, and that the best preparation for death is a life well lived. Once one is dead, nothing more can be done, by oneself, for obvious reasons, or by others. According to Jainism, one is sole determiner of one's own path (ibid., p. 136).

The Buddhists, though they deny an enduring self, do posit that the nexus of human pain and suffering (duhkha) resides in the residues of past karmas. The Jains similarly identify 148 karmic variations (prakrtis) that define and constrain the condition of the soul. Buddhists seek to understand the origins of pain through meditation, and hence gain release from its group. Jains seek to live a life of utmost purity to undo the knots (grantha) of karma. Both assent to the basic premises laid out in one of the six schools of Hindu thought, the Sāmphya Darśana. By examining the mechanics of rebirth as outlined in İśvarakṛ̣na's Sāṃkya Kārikā, the template for this important concept in Indian traditions can be discerned within a general conceptual framework.

\section{Sāmkhya: Emotions (bhāva) and the Transmigrating Subtle Body (sūkșma śarīra, linga)}

Sāmphya, one of the six foundational orthodox schools (darśana) recognized in Hinduism, sets forth a reciprocity between a seeing witness (purussa) and an ever-changing realm of mental, emotional, and physical activity (prakrti) arrayed in a play of three factors: dullness, passion, and illumination (tamas, rajas, sattva gunas). The word lingam appears in the Sāmkhya Kārikā (ca. 300 C.E.) several times to explain the basic constituents or marks of personality. Knowing a person's general disposition allows one to make inferences about how they might respond in a particular situation (SK 5). Dispositions or emotions (bhāvas) take many forms. In the aggregate, they determine one's personality. All aspects of the manifest world are colored or marked through the constitution 
of personality (SK10). The following sequence of verses explain the process of rebirth in largely psychological terms: ${ }^{1}$

39. Three distinct factors can be seen [in regard to life]:

subtle, born of a mother and father, and acts of will.

Subtle influences and acts of will in this life carry over to the next,

even though the body born of a mother and father will pass away.

40. The personality (lingam), which is cloaked with bhāvas,

has previously arisen but is not yet empowered.

It endures within the mahat to the edge of the subtle.

Because it has not experienced enjoyment, it transmigrates.

The bhāvas are the emotional states that govern human behavior. They are described in two schematics, one eightfold (to be explained below) and the other fifty-fold, accounting for the various ways in which an individual can survive and thrive or fail and fall. The mahat, like the alaya-vijñana in Yogācāra Buddhism, serves as the repository for all karmic impressions (samskāras or vāsanās) contained within the realm of Prakrti in her avyakta, her potential but as yet unmanifested form. In other words, certain yearnings remain unfilled. These desires, which reside in what modern psychologists might call the unconscious, fester and gnaw in a subtle state, seeking to be experienced.

41. Just as art requires color,

and just as without pillars there can be no shadows,

similarly, the personality cannot exist

without the specifics (of the bhävas).

The human person consists of a cluster of repeating experiences that arise due to one's past experiences, current accomplishments, and unfulfilled wants and dreams.

42. The personality performs like an actor

due to its connection (yoga) with the allurement of Prakrti.

This is the cause of human exertion:

yearning for both experience and its transcendence.

43. The bhāvas, including dharma and the others, are primary,

whether natural or acquired.

They are seen in the way life occurrences unfold

and in the growth of an embryo.

The argument is being made, in keeping with the satkaryavāda or realist philosophy of Sāmkhya, that the personality arises due to factors that carry over from one life to the next. In the next two verses, positive activities described in the bhāvas of dharma, jñanna, vairāgya, and aiśvarya, the dispositions of virtue, knowledge, non-attachment, and power, lead to positive results. Their inauspicious "evil twins" engender the opposite.

1 These translations are by the author in collaboration with Ana Funes, Ralph Craig III, Daniel Levine, Wijnanda Jacobi, Natale Fereira, and Nadia Pandolfo. 
44. With dharma, there is movement upwards.

Without dharma, things move downward.

With knowledge, freedom arrives;

from its opposite, bondage.

45. From nonattachment, things resolve themselves back into Prakrti.

From passionate attachment, saṃsāra continues.

From power, obstacles dissolve.

Otherwise, they persist.

The text goes on to itemize fifty variant forms, stating that the personality utterly relies upon the bhāvas (SK 52). The forms include the five states of affliction also listed by Yoga (avidyā, asmitā, raga, dveșa, abhiniveśa), 28 incapacities, nine complacencies, and eight perfections. ${ }^{2}$ By reflecting on how these various factors of personality stem from past influences and condition future experience, one can move toward a place of knowledge, which, according to the Sāmkhya system, is the only pathway to freedom.

\section{Yogananda: A Modern View of Reincarnation}

The 20th century Hindu Yoga teacher Paramahamsa Yogananda, in his commentary on the Bhagavad Gitta, provides an alternate description of what happens after death. According to Yogananda, the physical body perishes while the essence of a person ascends into a twofold astral and causal body:

In the physical world, the soul is encased in a fleshly body made of sixteen gross elements. After death, the soul is rid of its heavy overcoat of flesh but remains encased in its two other subtle garments - the astral body of nineteen subtle principles and the causal body of thirty-five ideas or thought forces ... when a man [sic] leaves the physical world in ignorance, he awakens in an astral world, encased in an astral body. In accordance with karmic law, he lives and develops in the astral for some time, working out some of his past tendencies. At the timing of cosmic law, man again experiences the death disintegration of the astral body and is reborn once more in the physical world. ${ }^{3}$

According to Yogananda, the human person is able to work out karmic issues while in the astral body in a process seemingly similar to what is described in the Tibetan Book of the Dead. Yogananda writes:

Then the ego sleeps for a while in the astral body, or is conscious of life in an astral world. After a while the ego begins to be disturbed by its innate subconscious material desires and by the muffled longing to express itself through a physical vehicle. At this time the cosmic law of karma, acting according to the desires and nature of the physically disembodied ego, sends it to be reborn on earth to parents similar in certain karmic respects to this wandering soul. (Ibid., p. 705)

2 Sāmphya retitles the Yoga categories descriptively as heaviness, delusion, great delusion, gloom, and utter darkness. The 28 incapacities start with the failure of the eleven sensory and action organs. Their inability to function results in deafness, lack of touch, blindness, inability to taste, inability to smell, severe digestive disorders, sexual dysfunction, inability to use the hands, paralysis of the legs, muteness, and insanity. This brings the total to 33. The other 17 include infirm bhāras dwelling in the buddhi or mahat, residues from past action that include inability to achieve the nine contentments and the eight powers. Four of the contentments are internal: satisfaction with the ways of nature, an innate proclivity toward spiritual practice, a reliance on the unfolding of time to resolve difficulties, and the notion that good luck governs all. The five external contentments arise from enjoying sound, touch, form, taste, and smell. The successes are eightfold: sound reasoning, the benefit of good instruction from a teacher, self-study, good friends, purity, and the overcoming of ignorance, weakness, and complacency. Each of these can present an opportunity for attachment and hence remain an impediment to freedom.

3 (Yogananda 1999). Jensen Martin thoughtfully shared these passages. 
Using biological language derived from 20th century science, Yogananda talks about sperm and ovum, adumbrating this physical explanation with discussions of astral light:

The parents to be unknowingly generate, during coition, an astral light of united positive negative currents in their coccygeal regions, which is referred to the sperm and ovum. When the sperm and its genetic and karmic potential from the father unities with the ovum and its pattern from the mother, there is a flash of astral light from this fertilized cell that attracts and guides the physically disembodied ego with its compatible karmic blueprint into the haven of its new primal cell of life. (Ibid.)

Adding colorful language regarding "disgruntled goblins", Yogananda further explains how the subtle tendencies lodged in the astral body seek expression in the physical realm:

At death, the sum total of man's tendencies are lodged in the brain of his luminous astral body. Mixed good and bad tendencies cause the soul to seek early rebirth in the physical world. When there is a predominance of good tendencies in the astral brain, the soul in its astral body encasement gravitates to a better environment on an astral planet. When evil tendencies predominate, the soul in its astral body gravitates to dark spheres of the beyond, where disgruntled goblin beings dwell. How long one remains in the brighter or darker astral regions before reincarnating on earth is karmically determined. (Ibid., p. 1025.)

Yogananda's details regarding the rebirth process interlace the traditional mechanics with some aspects of modern physiology and psychology. As a modern interpreter of Indian thought, Yogananda sought to explain reincarnation in terms that would make sense to his audience in the early 20th century while not contradicting teachings on reincarnation found in traditional literature.

Returning to the description of the rebirth process in classical Sāmkhya, as long as the bhāvas persist in defining the lingam, the person takes rebirth. Only with the ascent of knowledge (jñana) can one become free from the cycle of samsāra. This is a very specific form of knowledge that proclaims the abandonment of attachment to a fixed self, governed by desires, a formula found also in Buddhism: no doer, no self, no ownership: nāsmi, nāham, na me. All needs have been obtained. At death, one can look forward not to heaven nor to hell nor to birth in an animal or human realm, but an ascent to what the Jains call the Siddha Loka, a realm of undying repose and reflection.

Interestingly, this does not mean that the lives already lived are forgotten. One hallmark of the Buddha and of the 24 Jain Tirthankaras was that they remembered all the lives they had lived and the lessons learned in those lives. Patañjali's Yoga Sütra states that through the perfection of giving up all things, including psychological attachments, one spontaneously will remember past lives: "Firmly established in non-possession (aparigraha), one comes to know the why and how of past lives" (YS II:39). The Buddha recalled 550 past lives and used these memories to fuel many of his lectures. Mahavira remembered his past lives and also the past lives of others. In the Yogavāsiștha, Punya remembers the past lives of his grieving brother as well as his own prior experience. In the section that follows, narrative examples will be given from all three traditions, Buddhist, Jain, and Hindu.

\section{Buddhist Jataka Tales}

The Buddha told 550 stories of his past lives, recorded in the Theravada Canon. Half mention prior births of himself or others as animals or other non-human life forms. ${ }^{4}$ Many of the stories directly and obliquely relate to Devadatta, the cousin of the Buddha who tried to kill him by hurling rocks and sending a raging elephant toward him. In the Javasakuna Jātaka, the Buddha was living as a woodpecker who helped a lion who was choking on a bone. At a later time, when the woodpecker was in need, the lion refused, and received a verbal upbraiding from the bird. This lion later became Devadatta.

4 This material is summarized from (Tucker and Williams 1997). 
In another Devadatta story, a cruel elephant destroys a family of quail who take revenge by pecking out his eyes and lure the elephant to fall off a cliff to his death. The elephant in this story known as the Latukika Jātaka later becomes Devadatta.

In the Suvannamiga Jätaka, a stag became snared by a hunter. His devoted wife offered to sacrifice her life for the sake of her husband. The stunned hunter released both. The stag later returned to the hunter and implored him to give up killing. The stag later was reborn as the Buddha. In the Dummedha $J \bar{a} t a k a$, the Buddha recalls a past life as King of Varanasi. He recoiled at the excessive animal sacrifices performed by Brahmin priests and when he ascended the throne replaced this practice with vegetarian offerings to a banyan tree. In the Kusanjāli Jātaka, the future Buddha lived as a clump of grass under a beautiful tree. When the tree came under threat from woodsmen seeking a new central pillar for the palace of the king of Varanasi, the grass grew all night entwining itself into the tree causing it to look diseased. When the woodsman returned with their tools to fell the tree, they were convinced that it would not be suitable, thus sparing all the various forms of life that dwelt in and around the tree.

These Buddhist tales carry an implicit message: it is important to manifest positive qualities not only for the good of one's future birth, but for the sake of helping other living beings. Devadatta committed cruel acts life after life. The Buddha, in comparison, helped others, earning freedom for himself and bringing goodness to others.

\section{The Prince Who Was an Elephant: A Jain Tale of Rebirth}

Jainism posits that the soul (jīva) is eternal; it has existed from beginningless time and will live forever into an endless future. It takes birth after birth: elemental, microbial, as well as insect, fish, mammal, human, a god or goddess in one of several heavens, and, on occasion, as a dweller in one of numerous hells. Jain literature tells many stories of individuals who wander through various births before taking up the religious life and committing themselves to the practice of non-violence, essential for spiritual ascent. The goal of the Jain path is to move from the human realm to the Siddha Loka, the realm of perfect freedom, far beyond even the reach of the heavens.

In the Gyātasūtra of the Jain canon, also known as the Jnātadharmakathanga, the story of Meghkumar, or Cloud Prince, weaves past life memories in such a way that not only does a prince gain insight into his current state of affairs, but also in his immediate prior incarnation he recalls a lesson from an incarnation prior to that. Prince Meghkumar was born after his mother Dharinī recalled two dreams: one of a white elephant who came down from the sky and entered her womb through her mouth, and the second of an insatiable desire to ride through the city on a white elephant on a cloudy day. The king Shrenik and his queen consequently named their beloved son Cloud Prince and provided the happiest life possible for him, including his marriage to eight princesses.

Some years passed. The Tł̆rthankara Bhagavan Mahāvīra came to the capital of Shrenik's kingdom of Magadha, the city known today as Rajagriha. After hearing the Bhagavan speak, Prince Meghkumar decided to leave behind his wives and princely comforts to take up the life of a Jaina monk. The day before his initiation his father arranged for him to be king for a day, lending even greater weight to the significance of Meghkumar's renunciation. After the ceremony initiating Meghkuma into monkhood was completed, the former prince settled on the floor to sleep. As the most junior monk, he was required to sleep near the door. All night long, the monks came and went in order to relieve themselves in the field, disturbing his sleep. He tossed and turned, receiving no rest. He fell into a deep sadness and yearning for his prior life.

In the morning, he approached Bhagavan Mahāvīra and asked to be released from his vows. Using his powers of omniscience, the Bhagavan told two stories of Meghkumar's prior lives when he lived as an elephant. In one story, he was an elderly pure white elephant named King Sumeruprabh. A forest fire swept through his domain, forcing all the animals to flee. Because of his advanced age, Sumeruprabh stumbled and fell into a muddy lake bed. A younger elephant took advantage of his plight and gored him to death. 
The elephant was reborn again, this time as a bright red elephant named Meruprah, with four tusks, also king of his clan. While witnessing a fire from afar, he recalled the plight of his prior birth and urged his fellow elephants to clear an eight-mile meadow that would be safe in case of fire. Eventually, the summer fires came to the forest and all the animals, including antelope, deer, lions, jackals, cattle, and rabbits crowded into the meadow. Meruprabh lifted his foot to scratch his itchy stomach. A rabbit scampered into the space underneath his leg. For fear of killing the rabbit, Meruprabh stood on three legs for two and a half days. By this time, the fire had died down, but Meruprabh's leg had stiffened and he tumbled to the ground. He lay prone for three days, unable to move, suffering from pain, hunger, and thirst. However, because of the compassion he had manifested in order to save the rabbit, he felt peace even amidst the pain and took rebirth in the womb of Dharinī and was born as Prince Meghkumar. Having been reminded of this act of compassion, Meghkumar renewed his religious zeal and after twelve years of monastic life ascended to Mount Vipulchal where he engaged in a final fast, attaining a heavenly state as an angel in his next life. ${ }^{5}$

This story emphasizes the continuity of life from incarnation to incarnation. Elephants become elephants, and elephants become humans and humans become monks and monks become angels. Along the way, many other animals cross paths: antelope, deer, lions, jackals, cattle, and rabbits. One's actions toward other life forms determine one's status in the lives to come. If, even in the midst of a natural calamity such as a forest fire, one can seek to spare the lives of others, a reward will be gained.

Jain literature contains countless examples of rebirth narratives wherein the conditions and outcomes result in disgust toward and eventual abandonment of the world to pursue the monastic life. The merchant Maheśvaradatta discovered that his own presumed son was actually the reincarnation of a man he had killed while that same man made love to his unfaithful wife. A buffalo he had sacrificed in honor of his father was actually the reincarnation of his father and a nearby stray dog had been his mother (Granoff 1995). In the story of King Yaśodhara, the king discovers his wife committing adultery, who then poisons him and his mother. The poisoned mother and son are reborn in turn respectively as peacock and dog, mongoose and cobra, fish and crocodile, goat and goat, goat and buffalo, chicken and chicken, and finally again as twin children to the wife of Yaśodhara's son. The former king becomes a Jain monk and his mother becomes a Jain nun. They eventually fast to death and attain a heavenly realm. ${ }^{6}$

In Jain tradition, rebirth inevitably results in pain and misery. Monks and nuns recount these stories to inspire their lay students to understand the need to renounce the troubles of the world in order to avoid inauspicious rebirth. Eventually, as stated earlier, the goal is to ascend from human birth to the realm of perfection, a space beyond the heavens, wherein one dwells forever in a place of consciousness and bliss.

\section{The Story of Punya and Pāvana from the Yogavāsiṣtha}

The Yogavāsiștha, a Hindu text of Kashmir Śaivism also known as the Mokṣopāya that dates from the 1000s, includes a story of reincarnation that serves to underscore the connected nature of all forms of life. This story takes place on the Ganges River, where two brothers lose their parents. One laments excessively, prompting his older, wiser brother to use narrative to help bring his inconsolable brother back to a state of stability, a narrative that calls attention to the beauties of nature and the many forms of life that thrive upon the earth. ${ }^{7}$ The strategy of this particular story falls into the methodological category of narrative theology. By telling a story, the author engages the reader and listener in a real-life situation that highlights the pastoral aspects of reincarnation narratives.

5 Vijayji (n.d.). Inspiring Story of Meghkumar (Mumbai: Mahavir Seval Trust, n.d.) Jnatadharmakathanga (Nyayadhammakaao). The story is also in (Pupphabhikkhu 1952). It is also retold in (Jaini 2000b).

6 Summary of translation by Adam Hardy in (Granoff 1990).

7 This translation unfolded over the course of many months as a project of the Tuesday afternoon Sanskrit seminar at Loyola Marymount University. The translations are by Christopher Key Chapple unless otherwise noted and are based on the Sanskrit edition found in (Mitra 1998). 
The story begins by describing a lovely family whose aged parents grow old and die. The two remaining sons adopt different approaches to their loss. The elder son, Punya, sets about performing the required rituals, which are designed to ensure safe passage of their parents into the state of freedom. The younger son, Pāvana, becomes disconsolate. Here is where the usefulness of reincarnation as a belief system takes hold. The elder brother uses stories of past lives as a way to shake his younger brother out of his despondency. It had already been established that the parents were, as one often hears at a funeral, "in a better place":

19. With death, the father flew into samādhi,

free from thought, into the abode of consciousness.

He went to the stage free from passion,

like the scent of a flower wafts up into the sky.

20. His wife, having seen the body of the lifeless sage,

fell to the earth, like a lotus without a stalk.

21. Through the discipline of Yoga taught to her by her husband over many years, she renounced her delicate frame, like a bee flying from a lotus.

22. She followed her husband, departing to the place unseen by people, the light of her soul fading in the sky like the half moon at sunset.

As described above, the elder son did what needed to be done, while his younger brother floundered:

23. With mother and father gone, Punya steadfastly focused

on the funeral ceremonies, while Pāvana descended into grief.

24. His mind afflicted with grief, he wandered the forest paths.

Having lost sight of his brother, Pāvana wailed: “Aaaaah!”

25. Having performed the appropriate funeral rites

for the bodies of his mother and father,

Punya ventured into the forest after Pāvana, who was afflicted with great sorrow. ${ }^{8}$

26. "Why, boy, this thick cloud of sorrow? It is making you blind and ignorant.

Your violent cloud of tears is like a monsoon season filled with rain.

27. Your mother and father, of great wisdom, have gone together to heaven,

indeed, to that highest Self, that place called Mokṣa.

28. That place is the goal of all people who have overcome this world of form.

Why mourn your parents? They have attained their true nature.

29. You are really bound to this state that is born of delusion.

You mourn for things in samsāara that should not be mourned. 
This line echoes the message of the Bhagavad Gitta, which pronounces "the wise do not mourn for the living or the dead" (BG II:11). By reminding Pāvana of the larger picture, Punya undertakes a form of pastoral counseling.

30. She is not your only mother nor is he your only father.

Nor are we the only two sons of the many who have been born of those two.

31. Child, our mother and father have passed through thousands of births, as numerous as the streams running deep in each and every forest.

32. Honored son, we are not the only two sons.

Our parents have had countless children.

Multitudes of sons have passed through the generations like rapids in a river.

33. Our parents had innumerable distinguished sons

who have passed away long ago,

just as the branches of a creeping vine give forth many flowers and fruits.

34. Just as a great tree gives forth an abundance of fruits

with the passage of each season,

So also our many friends and relatives have experienced many births.

35. Son, if parents and children are to be mourned out of affection,

Then why should the thousands who die continually not also be mourned?

36. From your perspective of worldliness,

the affairs of wandering people are deemed important.

But from the highest perspective, knowledge reveals that

there is no lasting friend, no lasting relative.

37. On the other hand, brother, from the perspective of absolute truth, no destruction is known either.

Everything happens only in the mind and then evaporates like water in the desert.

38. The beautiful things that you see are none other than a dream,

fluttering like feathers on a parasol, lasting three or five days in the great mind.

39. By seeing things from the perspective of the ultimate reality, son,

You must regard this truth: 'There is neither you nor we.'

You must renounce all your confusion.

40. Realize that all your previous negative views are now dead and gone.

Such tortures arise in your own imagination and must not be seen as true.

41. In a death characterized by ignorance,

The rolling waves of pure and impure vibrations

Cause past impressions to manifest without interruption

into the realm of name and form, like moonlight on water. 
20.1. Who is the father? The friend? The mother? The relatives?

One's conception of them can be swept away as if they are dust in the wind.

2. Love, aversion, and delusion in regard to our friends, relatives, and offspring are merely accomplished by the projection of our own conceptions.

3. The quality associated with 'relative' makes a relative.

The quality associated with 'stranger' makes one a stranger, just as the conditions of poison or nectar depend upon the appearance of fixity (in the mind).

4. How can this notion arise that 'this one is a friend, that one is a stranger' when the mind of wisdom sees the oneness of the all-pervading soul?

5. Son, reflect on yourself through your mind.

Ask, 'Who am I? What could I be? Something other than the body?

A bony skeleton? A heap of blood, flesh, and bones?'

6. From the perspective of highest truth, there is no 'you,' there is no 'I.'

Only in delusion and ignorance do Punya and Pāvana spring forth.

7. Who is your father, who is your friend?

Who is your mother? Who is your enemy?

In regard to the endless luminosity of space,

What can be proclaimed to be the Self? Or not the Self?

After this philosophical reprimand, Punya then reminds Pāvana that he himself, like his parents and all other beings, have taken birth and rebirth countless times. He describes beautiful environments graced with trees, deer, and swans, reminding Pāvana of wider networks of family connections.

8. You are consciousness in the midst of many other prior births where you have had friends and properties.

Why do you not grieve for them also?

9. Those many deer in the flowery meadow, born of their mother does, were your relatives.

Why do you not grieve for them?

10. Regard the swans in the bouquets of lotuses on the riverbank.

Why do you not grieve for those swans who were your relatives?

11. Those fine trees in the splendid beautiful forests were also your relatives.

Why do you not grieve for them?

12. Those lions on the awe-inspiring peaks of those mountains were also your relatives. Why do you not grieve for them?

13. Those fish among the beautiful lotuses in the clear lakes were also your relatives. Why do you not grieve for them? 
14. You were a monkey in the brown woods of the Ten River Land, a prince in the land of snow, and a crow in the forest of the Pundras.

15. You were an elephant among the Haihaya people, a donkey in the company of the Trigartas, a puppy with the people of Salva, and a bird in that tree.

16. You were a fig tree in the Vindhya range, and an insect in a great tree.

You have been a hen on the Mandara Mountain.

You were born also as a Brahmin in Kandar.

17. You were a Brahmin in Kośala. You were a partridge in Bengal.

You were a horse in the land of snow.

And you were the beast killed at the Brahmana sacrifice.

18. The one who was an insect inside the root of a palm tree, who was a mosquito on a big ficus tree, the one who was previously a crane in the forest, that one is now you, my son, my little brother.

19. That small red ant that lived for six months in the hollow of the thin knotty birch tree bark on the cliffs of the Himalayas is now you, my little brother. ${ }^{9}$

20. You were the beetle living for a year and a half in cow dung at the edge of a frontier village. O Sadhu, that was you, little brother. ${ }^{10}$

21. The child who sat on the six petalled lotus throne of the Pulinda tribal woman, hidden in the forest, that one was you, little brother.

22. For thousands of prior births in these many woods you were born of various wombs, my son,

And now you are born on Jambudvipa.

23. By the purified clear vision of my subtle intellect, I see the previous successive lives of your self.

Punya also remembers his own past lives as a parrot, a frog, a lumberjack, a "Don Juan," a bird, a king, a tree, a tiger, and more.

24. I remember today my many past lives, born of many wombs due to ignorance and indolence. This insight has arisen due to knowledge. 
25. Having been a parrot in Trigarta and a frog on a riverbank, and having been a lumberjack in the woods, now I am born here in this forest.

26. I ravished a royal woman in the Vindhyas.

I have been fashioned as a tree in Bengal as well as a camel in the Vindhya range.

I am now born in this forest.

27. That bird in the Himalayan town, that king in the Paundra region, that tiger in the Salya region ... that one is now me, your elder brother.

28. I was that vulture who lived for ten years, that shark who lived five months, and that lion who lived a full century. That one indeed is now your older brother.

29. Can you believe it? I lived as a prince of a village in Andhra, as a sovereign king in the Tuṣāra region, and as the son of the Śailācārya.

30. I remember from long ago all the various incarnations and all the various customs that have arisen into manifestation due to confusion.

31. There, in that place [of memory], so many thousands of relatives were born in those worlds that have now gone: fathers, mothers, siblings, and friends.

Having held forth like a circuit preacher on the various times and places that both he and his brother have taken birth, Punya then delivers a homily designed to stabilize his younger brother's mind and emotions.

32. Whom shall we two grieve? Whom shall we not grieve?

We grieve all relatives that die. This is the way of life in the world.

33. Like the endless passing of fathers and mothers in this world of samsāra, souls drop like leaves, falling off the trees in the forest. ${ }^{11}$

34. Who can measure the varieties of pleasure and pain, O brother?

Therefore, renounce all of them. Let us take our place in the light.

35. Having renounced all cultivation of outward manifestation in the mind, abiding in the Self, go happily to that place, that place where the wise ones go.

36. Inactive beings fall away. Active persons rise again.

Those with good thoughts do not grieve. They move gradually toward freedom.

37. Be free of confusion. Be free of [attachment to] existence and nonexistence.

Escape from old age and death. Be cool, always remembering your true Self.

38. You are not your suffering. You are not this birth.

You are indeed the Self, not this intellect.

Indeed, how could you be other than true Self?

11 Translation by Natalé Ferreira. 
39. Good man, ignorant people performing various dramas in this journey of samsāra attach themselves to the sentiments of existence.

40. One can attain the goal of being the witness, self-possessed in the midst of all that can be seen.

Such persons are established in the dharma of the observer, being the knower and spectator at all times.

41. Whether engaged in action or inactive,

such persons regard actions as if they were the fading light

at the start of the night. The knower stands unperturbed by the world.

42. Those who have arrived at the illumination of the true Self

no longer see the reflection [as real], just as the jewels reflected in the mirror

are taken to be mere reflections by those with wisdom.

43. Through moving away from all this self-made darkness, dwell in your true Self, which is like the radiant moon in the middle of your heart.

44. Son, find the Self in the Self. Be a sage like the great sages.

Having renounced all impure perplexity, be content!

This narrative, told over two chapters of the Upaśama Prakarana of the Yogavāsiștha, holds many insights Hindu attitudes toward reincarnation. We are not limited beings. We carry unfathomable histories and experiences; according to Hinduism, Buddhism, and Jainism, we have taken birth countless times. By adopting the long view suggested by Punya, that is, being cognizant of the wide range of past lives, we can move beyond the petty dramas that trap the mind and emotions in negativity. This does not mean that grief is to be avoided; Pāvana channeled his grief into the performance of the funeral rituals. Pāvana suggests that we must always take the wider perspective, surrendering attachments in favor of contentment and peace.

\section{Implications}

The mechanics of reincarnation are complex. All the traditions seem to agree that actions (karma) from the past determine one's present and future states. The residues of action (samskāras or vāsanās) in the case of Hinduism are released at the time of cremation and enter a period of transition that includes ascent into smoke, descent with rain into the earth, ascent into the stuff of food and semen, and eventual new life through the reproductive process. For Buddhists, the bundle of unresolved desires travels for 49 days of the funerary period in a subtle form before finding a new birth. For Jains, the karmic bundle moves directly from death into a new womb, already determined by actions performed toward the end of life. These three descriptions of how rebirth takes place are markedly different. The Hindus tend to a very physical explanation, while the Buddhists and Jains emphasize psychological states and yearnings. The Buddhist intermediary period of 49 days allows for the possibility that petitionary prayer by others may guide one toward a more auspicious rebirth, while the Jains place responsibility for one's next birth solely and squarely on the will and initiative of the individual.

The Kausittaki Upanishad takes a mechanistic view of the rebirth process. Do good and you will ascend to a better birth. Commit acts of evil and descend to a lower, animal birth. The Buddha used rebirth stories to convey ethical allegories and to chastise his listeners to remember the consequences of their actions. The Jain rebirth stories emphasize the continuity between animal and human life forms. The story of Punya and Pāvana provides a way of coping with grief by seeing the larger frame of repeated birth and rebirth. 
Each of the narratives contains a message that serves to inspire a move away from attachment toward a state of acceptance and peace. The Jain stories of the reincarnations of merchants and kings encourage wariness of rebirth into the world of samsara. The narrative of Punya and Pāvana, rather than engendering feelings of disgust in regard to the world, shows the healing powers of connecting with animals and a broader sense of the beauties of nature in order to find solace and healing in a time of grief.

These stories of rebirth give voice to the ethic of nonviolence, the keystone of Jain and Buddhist and Hindu religious practice. In the Buddha's retelling of his own past lives, his virtue helped move him toward his eventual freedom. In the case of Jainism, the elephant, highly sensitive and intelligent, retained memories over a course of three lifetimes, using profound intelligence to help solve the recurrent problem of how to cope with wildfires. His profound emotional intelligence carried over from one lifetime to the next. In Hinduism, the insight and kindness of the elder brother Punya empowered him to cajole his younger brother out of his depression through regaling him with past life stories. Lessons from past lives shape and guide an individual into present and future lives. To have been an animal and to have recalled past animal experiences indicates a sign of greatness, an acknowledgement of one's ongoing connections and kinship with other species.

According to the Yoga Sütra, recollection of past lives arises when one is able to relinquish all clinging, all possessions. Through this process of release, one comes to understand the operations of karma. Rather than clinging, regretting, or lamenting, one moves into the mode of acceptance.

Krishna teaches Arjuna in the Bhagavad Git $\bar{a}$ the need to see the beginning and end of things as both inevitable and linked to an underlying sense of the eternal:

II:22. Just as a person casts off clothes and takes on new ones,

so the embodied one casts off worn-out bodies

and takes on others that are new.

26. Even if you think this is perpetually born

and perpetually dying, even so, Strong Armed One,

you should not grieve for this.

27. For to one born, death is certain,

and to one dying, birth is certain.

Therefore you must not grieve over what is unavoidable.

28. Beings are unmanifested in their beginnings,

apparent in their middle, and unmanifested in their ends.

What in this is to be lamented?

30. The embodied one in the body of each

is eternal and invulnerable.

Therefore, Arjuna, you must not grieve for any being! (DeNicolas 2004)

Knowing that the unfolding of life originates from seeds of karma, and understanding that these seeds will sprout, grow new fruit, ripen, and give way to new seeds, a sense of the flow of life can give comfort and solace. Rather than remaining attached to every single experience, through acceptance of rebirth, one can take the long view rather than obsessing over the preciousness of this very life. Whereas the poet Mary Oliver posed the question, "What is it that you plan to do with your one wild and precious life?" the teachings of reincarnation take a different approach, one that could perhaps be phrased as "How will you explore the many lives you have been and the many lives you will become?" 
Teachings of reincarnation provide moral fables. As a form of narrative theology, reincarnation stories hold important pastoral implications. These stories, grounded in an expansive ontology and cosmology, encourage the listener to consider the ethical imperatives within one's own life.

Conflicts of Interest: The author declares no conflict of interest.

\section{References}

DeNicolas, Antonio T., trans. 2004, The Bhagavad Gita: The Ethics of Decision-Making. Berwick: Nicolas Hayes, pp. 33-34.

Phyllis Granoff, ed. 1990. The Clever Adulteress and Other Stories: A Treasury of Jain Literature. Oakville: Mosaic Press.

Granoff, Phyllis. 1995. The Story of Maheśvara from the Dharmābhyudayamahākārya. In Religions of India in Practice. Edited by Donald S. Lopez Jr. Princeton: Princeton University Press, pp. 413-14.

Jaini, Padmanabh S. 2000a. Karma and the Problem of Rebirth in Jainism. In Collected Papers on Jaina Studies. Delhi: Motilal Banarsidass, p. 132.

Jaini, Padmanabh S. 2000b. Collected Papers on Jaina Studies. Delhi: Motilal Banarsidass, p. 261.

Mitra, Vihari Lal. 1998. The Yoga-Vāsiștha of Vālmīki Sanskrit Text and English Translation, Vol. II, Sthiti Prakarana, Upaśama Prakarana. Edited and Revised by Ravi Prakash Arya; Delhi: Parimal Publications, pp. 254-60.

Pupphabhikkhu, ed. 1952. Suttagame, Part 9. Gudgaon: Sutragamaprakashaka Samiti.

Tucker, Mary Evelyn, and Ryūken Williams. 1997. Animals and Environment in the Buddhist Birth Stories. In Buddhism and Ecology: The Interconnection of Dharma and Deeds. Cambridge: Harvard University Center for the Study of World Religions, pp. 131-48.

Vijayji, Muni Shri Purnachandra. n.d. Inspiring Story of Meghkumar. Mumbai: Mahavir Seval Trust.

Yogananda, Paramahamsa. 1999. The Bhagavad Gita: Royal Science of God-Realization. Los Angeles: Self Realization Fellowship, p. 230.

(C) 2017 by the author. Licensee MDPI, Basel, Switzerland. This article is an open access article distributed under the terms and conditions of the Creative Commons Attribution (CC BY) license (http://creativecommons.org/licenses/by/4.0/). 